\title{
HIGHER EDUCATION IN INDIA- KNOWLEDGE AND ATTITUDE AMONG MEDICAL \& NON-MEDICAL STUDENTS IN SELECTED COLLEGE OF BAREILLY.
}

\author{
Mrs. Anjana Matho ${ }^{1}$ Ms. Rebecca Emmanuel ${ }^{2}$ Dr.C. LathaMangeswari ${ }^{3}$ Prof. Arvind $^{\text {Ema }}$ \\ Kumar Jangid ${ }^{4}$ \\ ${ }^{1}$ Asst.Professor, Jyoti College of Management, Science \& Technology, Bareilly \\ ${ }^{2}$ Nursing Tutor, Jyoti College of Management, Science \& Technology, Bareilly \\ ${ }^{3}$ Principal, Jyoti College of Management, Science \& Technology, Bareilly \\ ${ }^{4}$ Professor, Jyoti College of Management, Science \& Technology, Bareilly
}

\section{ABSTRACT}

AIM: The aim of the research was to assess the knowledge and attitude among medical and nonmedical students towards higher education in India at selected colleges in Bareilly.

METHOD: A quantitative study was carried out with the structured questionnaire regarding higher education in India to elicit information from $(n=200)$ medical and non-medical students selected by Non-probability convenient sampling technique. RESULTS: In the Study $86 \%$ of the students were in 18-23 years of age group, $63 \%$ were female. $70 \%$ of the students from Urban and $72 \%$ had their schooling also in Urban. Among the participants $92 \%$ of them said that they know the importance of quality in higher education $91 \%$ accepted that the technical study is needed for higher education. 51\% of them highlighted that research has less benefit as for higher education. Regarding attitude of the students $96 \%$ of the students wish to have development of quality educational institutions $94 \%$ of them accepts that higher education helps in meeting societal and industrial demands, but $50 \%$ said getting higher education is difficult nowadays. Among the participants only $27 \%$ of them are willing to respect the professionals. CONCLUSION: The study results highlights that there is a significant gap between knowledge and attitude of the students regarding higher education in India.

Key words: Higher Education, Attitude, Knowledge, Medical and Non-Medical Students. formed but only on papers some of them

\section{INTRODUCTION:}

"Education is the most powerful weapon which you can use to change the world"

\section{Nelson Mandela}

Higher education is a best thing that we can gift to the upcoming generation. In India, due to some lacking in educational system most of our children and youth are not having the quality education. All of the people in India are not getting equal education. In India lots of policies has been dies on paper only, it is difficult for people to reach to them. According to Amartya Sen (Nobel Laureate) in 1970 in one of his lectures told that he analyzed the Crisis in Indian education system. He emphasized that due to government tendency to formulate educational policies most of time was based on public pressure and due to which often wrong policies are pursued. 
Higher Education plays a vital role in achieving sustainable and inclusive growth of any country. It is an important input in the process of economic growth through its contribution to human capital. Indian Constitution made free and compulsory education to children between the ages of 6 and 14 as a fundamental right. The vision of higher education in India is to realize the country's human resources potential to its fullest extent with equity and inclusion. The higher education sector, in recent decades has witnessed a remarkable growth in its institutional capacity, enrolment, teacherstudent ratio, funding, etc. The rapid expansion of the higher education system at the same time has brought several issues related to equity, efficiency, excellence and access to higher education. Government of India aimed at increasing Gross Enrolment Ratio (GER) in higher education to $21 \%$ during the Twelfth five year plan (201217).[1]

In today's India it is difficult for an average class individual to reach higher education. As per the latest 2011 survey about $8.15 \%$ of Indians are graduates which is very much minimal[2]. This is the bitter truth and we all have to face it with harsh experiences by which interest of getting higher education reduced and unemployment rates have been increased. Unemployment in India statistics has traditionally been collected, compiled and disseminated once every five years by the Ministry of Labor and Employment (MLE), primarily from sample studies conducted by the National Sample Survey Office $(3,4)$ Other than these 5-year sample studies, India has - except since 2017 - never routinely collected monthly, quarterly or yearly nationwide employment and unemployment statistics. In 2016, Centre for Monitoring Indian Economy - a nongovernment entity based in Mumbai, started sampling and publishing monthly unemployment in India statistics $(5,6)$. Unemployment is a major social issue in India. As of September 2018, according to the Indian government, India had 31 million jobless people (7).

\section{Quality Concept Of Higher Education In India}

According to All India Survey on Higher Education (Research Scholar, Department of Education, Aligarh Muslim University, Aligarh, Quality is perceived differently by different people. Yet, everyone understands what is meant by "quality." In a manufactured product, the customer as a user recognizes the quality of fit, finish, appearance, function, and performance. The quality of service may be rated based on the degree of satisfaction by the customer receiving the service. The relevant dictionary meaning of quality is "the degree 
of excellence." It means there must be some important criteria, characteristics, distinguished element of a product, organization or institutions that gives satisfaction to the people who avails the service. It is connected with the feeling of satisfaction and perception of the people.

A definition attributed to quality guru Crosby (1979) states that, "quality is conformance to requirements." Another frequently used definition comes from Juran et al. (1988) as he said that, "Quality is fitness for use." This definition stresses the importance of the customer who will use the product. W. Edwards Deming (1986) defined quality as "Good quality means a predictable degree of uniformity and dependability with a quality standard suited to the customer" Seymour (1992) opines that -quality is continuous improvement. In the context of education, quality is "the ability to meet the stated purpose for which the service was offered" (Powar, 2001).

India has got huge achievement in the higher education and supplies huge number of human resource not only in India but also in the global market. Large number of technicians from different technological institutions, doctors, business managers, scientists and researchers are doing their business outside India with excellence that is the result of Indian higher education. But as cumulative results, the Quality of Indian Higher Education is still in very poor condition. The poor quality of higher education is a serious issue. It is the opinion of different stakeholders, academicians, office bearers, politicians and different policy makers that the quality of higher education could not keep the required pace of development with the changes in technology, new trends of education system, occupational diversity, global market trends and so on from time to time. The students who complete their UG and PG course have very low job opportunities.

Another serious issue is the gap between demand and supply implying that the youths are not eligible for the job market. This leads to wide spread unemployment among the higher educated graduates. To improve the quality of higher education in India, we must maintain

Parameters of quality education. The parameters of quality higher education are: sufficient number of quality faculty members, profile of the students entering into the higher education, infrastructure of the educational institutions, curriculum, appropriate teaching method, examination pattern, learning resources, national agencies, government policies and institutional leadership etc. India has one of the largest education systems of the world. Therefore, different stakeholders 
must work on these parameters on their respective levels to maintain and improve the quality of higher education in India.[8]

According to Sanyal and Martin, 2006, shared that reforms in China's higher education are initiated along with other economic reforms, when China decided to become a market economy in the year 1978 . Prior to that higher education was in public sector. There was no tuition fees for education. But, after 1978 when China became a market economy, Tuition fees have now been made compulsory. According to UGC Data on Higher education system in India for the year 20142015 is about 329 state Universities, 46 central universities, 128 deemed to be universities, 74 institutions of National importance, and 205 State private university and institutions functioning in the country, Besides the reputation of larger highest education system and network, It is revealed by different sources and surveys that quality of higher education has been provided by various institutions is not satisfactory, according to the times higher education ranking of worlds universities \& research institutions no Indian university or institution has find his position within the top hundred universities/ institutions of the world in the year $2015-16$. From the surveys of various reputed international organizations it has been clearly found and revealed that the quality of higher education provided in India is quite low standard compared to various top ranked world universities and research institutions.

\section{Quality Concept of Higher Education in} India

Quality is perceived differently by different people. Yet, everyone understands what is meant by "quality." In a manufactured product, the customer as a user recognizes the quality of fit, finish, appearance, function, and performance. The quality of service may be rated based on the degree of satisfaction by the customer receiving the service. The relevant dictionary meaning of quality is "the degree of excellence." It means there must be some important criteria, characteristics, distinguished element of a product, organization or institutions that gives satisfaction to the people who avails the service. It is connected with the feeling of satisfaction and perception of the people.

A definition attributed to quality guru Crosby (1979) states that, "quality is conformance to requirements." Another frequently used definition comes from Juran et al. (1988) as he said that, "Quality is fitness for use." This definition stresses the importance of the customer who will use the product. W. Edwards Deming (1986) defined quality as "Good quality means a 
predictable degree of uniformity and dependability with a quality standard suited to the customer."

\section{CMIE Reports}

According to the Centre for Monitoring Indian Economy Private Limited, India has never tracked and published monthly, quarterly or yearly employment and unemployment data for its people. This may have been a political convenience, states Mahesh Vyas, as "no measurements means there are no [political] arguments" about unemployment in India. The Centre for Monitoring Indian Economy, a nongovernment private entity, started to survey and publish monthly unemployment data for the first time in Indian history in 2016 (9).

\section{Research in Higher Education}

The higher education sector in India spends $4.1 \%$ of country's research fund. It is $17.0 \%$ in Germany; $22.6 \%$ in U.K. and $10.1 \%$ China. The research manpower in China is 8.6 lakhs; in

India 1.3 lakhs and even in Korea it is 1.5 lakhs. Higher education scene in India should needed to be looked into. Every institution has Lecturers, Assistant professor, and Professor; and all are expected to do research. In India, higher education is in the affiliated colleges which are 22000 in number. They have no Professor; not even Assistant professors necessarily. Ninety percent $(90 \%)$ of our undergraduate students and $66 \%$ of our postgraduate students; and $84 \%$ of our faculty in higher education are in the affiliated colleges. There is no research in the affiliated colleges; this means that in the field of higher education $84 \%$ of faculty members do not do research. They are not expected to do research and only $16 \%$ of the faculty in higher education is expected to do research in the country. How can university research prosper with such grossly inadequate numbers not engaging in research, in comparison with the entire higher education faculty being expected to do research in advanced countries? The India higher education sector should spend more money for research and motivate faculty of higher education working in affiliated colleges.

\section{Research In Higher Education}

The higher education sector in India spends $4.1 \%$ of country's research fund. It is $17.0 \%$ in Germany; $22.6 \%$ in U.K. and $10.1 \%$ China. The research manpower in China is 8.6 lakhs; in India 1.3 lakhs and even in Korea it is 1.5 lakhs. Every institution has Lecturers, Assistant professor, and Professor; and all are expected to do research. In India, higher education is in the affiliated colleges which are 22000 in number. They have no Professor; not even Assistant professors necessarily. Ninety percent $(90 \%)$ of our undergraduate students 
and $66 \%$ of our postgraduate students; and $84 \%$ of our faculty in higher education are in the affiliated colleges.

There is no research in the affiliated colleges; this means that in the field of higher education $84 \%$ of faculty members do not do research. They are not expected to do research and only $16 \%$ of the faculty in higher education is expected to do research in the country. The India higher education sector should spend more money for research and motivate faculty of higher education working in affiliated colleges.[10] Nartgun and Eren (2007) conducted a study on education policies of Turkish political parties and their possible effects of economic development. The findings of the study show that equality of opportunity is the common issue in the education policies of the parties. Equality of opportunity is Review of Related Literature 68 included in the policies of all parties shall ensure that all individuals benefit from the existing educational opportunities and that current human resources are utilized at the maximum level.

Tilak (2007) conducted a study on postelementary education, poverty and development in India. The study shows that post elementary education is important for reduction poverty, in improving infant mortality and life expectancy, and for economic growth.

\section{Challenges In Higher Education In India}

UGC is continuously working and focusing on quality education in higher education sector and facing lot of problems and challenges in our education system. Some of the basic challenges in higher education system in India are discussed below:

- Enrolment: The Gross Enrolment Ratio (GER) of India in higher education is only $15 \%$ which is quite low as compared to the developed as well as, other developing countries. With the increase of enrolments at school level, the supply of higher education institutes is insufficient to meet the growing demand in the country.

- Equity: There is no equity in GER among different sects of the society. According to previous studies the GER in higher education in India among male and female varies to a greater extent. There are regional variations too some states have high GER while as some is quite behind the national GER which reflect a significant imbalances within the higher education system.

- Quality: Quality in higher education is a multi-dimensional, multilevel, and a dynamic concept. Ensuring quality in higher education is amongst the foremost challenges being faced in India today. However, Government is continuously focusing on the quality 
education. Still Large number of colleges and universities in India are unable to meet the minimum requirements laid down by the $\mathrm{UGC}$ and our universities are not in a position to mark its place among the top universities of the world.

- Infrastructure: Poor infrastructure is another challenge to the higher education system of India

\section{Suggestions Improving The System}

\section{Of Higher Education:}

- There is a need to implement innovative and transformational approach form primary to higher education level to make Indian educational system globally more relevant and competitive.

- Higher educational institutes need to improve quality and reputation.

- There should be a good infrastructure of colleges and universities which may attract the students.

- Government must promote collaboration between Indian higher education institutes and top International institutes and also generates linkage between national research laboratories and research centres of top institutions for better quality and collaborative research.

- There is a need to focus on the graduate students by providing them such courses in which they can achieve excellence, gain deeper knowledge of subject so that they will get jobs after recruitment in the companies which would reduce unnecessary rush to the higher education.

- Universities and colleges in both public private must be away from the political affiliations,

- Favoritism, money making process should be out of education system etc.

- There should be a multidisciplinary approach in higher education so that students knowledge may not be restricted only up to their own subjects[11]

\section{Aim}

The aim of the study was to assess the attitude \& knowledge among medical and non-medical students towards higher education and especially the importance of conducting research in higher education in selected college of Bareilly.

\section{Method and Materials}

A descriptive, quantitative study was conducted in January 2020 in Jyoti College of Management Science \& Technology Bareilly. The prior written consent was taken from the principal of each department of college. Through a simple random sampling method, 100 students of nursing (40 of GNM III year, 40 GNM II Year \& 20 
from B.Sc nursing), 50 from paramedical, and 50 from department of education. Total 200 students participated.

Verbal explanation about this study was given to the students. Code numbers were given to maintain anonymity of the students. The demographic details of the students such as age, gender, department of study, literacy of parents, monthly income of parents, area of living, area of schooling, information regarding the $1^{\text {st }}$ generation to be graduated were collected in Questionnaire Part I . The knowledge and attitude level of the students were assessed by using structured Higher Education Assessment Questionnaire on knowledge and attitude by

checklist, (HEAQ- K-A 20). It consisted of 10 questions and each item was selected and modified according to the level of students' knowledge, student group, cultural value and attitude regarding higher education.

Attitude Score 0-5 Negative Attitude and

\section{5-10 Positive Attitude}

\section{Dependent variable:}

Knowledge and attitude of the students regarding higher education in India were the dependent variables.

\section{Attribute variable:}

Age (in years), Gender, Living environment /area, School education, Family monthly income, Department of study, Education level of parents, 1st graduate person in family are the source of information related to higher education in India are attribute variables.

\section{Tool Development and Description}

A structured questionnaire and a checklist were developed for assessing the knowledge and attitude regarding higher education in India. The tool was prepared on the basis of the objectives of the study with the following steps:

- Review of literature provided adequate content for the tool preparation.

- Researcher's personal experience, consultation with experts and discussion with peer groups.

- Prior to structuring the questionnaire the investigator visited various departments of Jyoti college of Management, Science \& Technology and collected relevant data necessary to construct the items for the knowledge \& Attitude questionnaire.

- Prior to preparation of the checklist the investigator assessed the attitude of the students regarding Higher Education in India.

- Construction of demographic variables, structured knowledge questionnaire and checklist to assess knowledge and attitude regarding higher education in India. 
- Abstained Content Validity and Reliability of the tool.

Part - I- Demographic Variables with Age (in years), Gender, Living environment / area, School education, Family monthly income, Department of study, Education level of parents, 1st graduate person in family and the source of information related to higher education in India are included.

Part -II- Questions assessing knowledge about Higher Education Assessment with simple Questionnaire on knowledge (10 simple close ended question) in broad

aspects comprising on awareness about status of Higher education in India. The score for correct answer is 01 and wrong answer 0 . The score ranges from 0-10.

Part -III: A checklist (Likert's scale) comprising of questions assessing attitude about Higher Education in India with (10 items), which are positively stated and negatively stated items. For positive statement, agree-01 and disagree 00. For negative statement agree- 01 and disagree 00 , attitude score interpretation was calculated as total score 0 to 10 -Two subscale scores 05-10 - Positive Attitude 0-05 - Negative Attitude.

\section{Ethical Consideration}

Prior to data collection, permission was obtained from the concerned authorities of Jyoti College of Management Science and
Technology, Bareilly to conduct the study and from the Students, regarding willingness to participate in the study, only were included. The investigator obtained consent from subjects. Confidentiality was maintained during data collection.

\section{Tool Validity and Reliability}

Validity of the tool obtained from the 3 experts, comprising of one Professor from Nursing, one Professor from Education Department and one Statistician.

\section{Pilot Study}

The pilot study was conducted among $10 \%$ of non-study subjects selected at a non-study area by using convenient sampling technique. Data analysis of the pilot study was done to ensure the effectiveness of the main study. The findings revealed that most of the subjects were having inadequate knowledge and unfavorable attitude regarding higher education considering the results and opinion of experts, the investigator decided to carry out adetailed study.

\section{Data Collection and Analysis}

By considering all the ethical aspects the main study was conducted for one week. The investigator given self-introduction an $d$ explained the purpose of the study. The data was collected by using structured questionnaire and checklist (Likert's scale) to each of student. It took about 25-30 minutes per sample to collect the data. The 
responses were recorded in the space provided in the questionnaire itself followed by which data was analyzed by using frequency, mean and standard deviation. Frequencies and percentages were used for the analysis of demographic data, Mean and SD were used to discuss the knowledge and attitude level of students on Higher education in India.

\section{Result and Discussion}

In the Study $86 \%$ of the students (Table.1) were in 18-23 years of age group. The significance of this group is that they are only involved a lot in choosing and undergoing the higher studies. This is the major age group people have most defined perspective regarding Higher education. They are more interested in educational activities. According to Statistics of Higher and Technical Education publication (2014) and AISHE (2014) there has been an improvement in the gross enrolment ratio of student being enrolled in higher education from 8.1 in $2001-2002$ to 21.1 in 2012-2013.[12]. 50\% of the Family monthly income is Rs. 20,000 and less showed the lower middle class Economical background of the students. Only $21 \%$ were the first graduate person in family conveys the message that education for the first graduate in a family is struggling still. $12 \%$ of the parents who are not educated could make their children educated.
Table 1. Demographic Variables

\begin{tabular}{|c|c|c|c|}
\hline S.n & Variables & No. & $\%$ \\
\hline 1 & $\begin{array}{c}\text { Age (in years) } \\
\text { a) } 18-23 \\
\text { b) } 24-28\end{array}$ & $\begin{array}{c}172 \\
28\end{array}$ & $\begin{array}{l}86 \% \\
14 \%\end{array}$ \\
\hline 2 & $\begin{array}{l}\text { Gender } \\
\text { a) Male } \\
\text { b) Female }\end{array}$ & $\begin{array}{c}74 \\
126\end{array}$ & $\begin{array}{l}37 \% \\
63 \%\end{array}$ \\
\hline 3 & $\begin{array}{l}\text { Living environment / area } \\
\text { a) Urban } \\
\text { b) Rural }\end{array}$ & $\begin{array}{c}140 \\
60\end{array}$ & $\begin{array}{l}70 \% \\
30 \%\end{array}$ \\
\hline 4 & $\begin{array}{l}\text { School education } \\
\text { a) Urban } \\
\text { b) Rural }\end{array}$ & $\begin{array}{c}144 \\
56\end{array}$ & $\begin{array}{l}72 \% \\
28 \%\end{array}$ \\
\hline 5 & $\begin{array}{l}\text { Family monthly income } \\
\text { a) Rs. } 20,000 \text { and less } \\
\text { b) Rs. } 21000-40,000 \\
\text { c) } 41,000 \text { and above }\end{array}$ & $\begin{array}{c}100 \\
60 \\
40\end{array}$ & $\begin{array}{l}50 \% \\
30 \% \\
20 \%\end{array}$ \\
\hline 6 & $\begin{array}{l}\text { Department of study } \\
\text { a) Department of } \\
\text { nursing } \\
\text { b) Department of } \\
\text { education } \\
\text { c) Department of } \\
\\
\text { paramedical }\end{array}$ & $\begin{array}{c}100 \\
50 \\
50\end{array}$ & $\begin{array}{l}50 \% \\
25 \% \\
25 \%\end{array}$ \\
\hline 7 & $\begin{array}{l}\text { Educational level of parents } \\
\text { a) Graduated } \\
\text { b) School education } \\
\text { c) Not educated }\end{array}$ & $\begin{array}{l}96 \\
80 \\
24\end{array}$ & $\begin{array}{l}48 \% \\
40 \% \\
12 \%\end{array}$ \\
\hline 8 & $\begin{array}{l}1^{\text {st }} \text { graduate person in } \\
\text { family } \\
\text { a) Yes } \\
\text { b) No }\end{array}$ & $\begin{array}{l}22 \\
158\end{array}$ & $\begin{array}{l}21 \% \\
79 \%\end{array}$ \\
\hline
\end{tabular}

TABLE. 2 Knowledge and Attitude On Higher Education In India

\begin{tabular}{|c|c|c|c|c|c|c|c|}
\hline \multicolumn{4}{|c|}{ Knowledge } & \multicolumn{4}{|l|}{ Attitude } \\
\hline $\begin{array}{l}\text { Gradi } \\
\text { ng }\end{array}$ & $\begin{array}{l}\text { Percentage } \\
\%\end{array}$ & Mean & $\mathrm{SD}$ & Grading & $\begin{array}{c}\text { Perce } \\
\text { ntage } \\
\%\end{array}$ & Mean & $\mathrm{SD}$ \\
\hline Fair & $49 \%$ & \multirow[t]{2}{*}{7.01} & \multirow[t]{2}{*}{1.70} & Fair & $27 \%$ & \multirow[t]{2}{*}{7.73} & \multirow[t]{2}{*}{1.60} \\
\hline Poor & $51 \%$ & & & Poor & $73 \%$ & & \\
\hline
\end{tabular}

Among the participants (Table. 2) 49\% have

fair knowledge and $51 \%$ have poor 
knowledge with mean of 7.01 and SD 1.70. $92 \%$ of them said that(Table.3) they know the importance of quality in higher education and $91 \%$ accepted that the technical study is needed for higher education but $51 \%$ of them highlighted that the research has less benefit as for higher education which aspect is mismatching with their previous knowledge. That indicates that the education which is practiced is not giving importance to Research which is the most important part of real education.

\section{TABLE-3. Assessment of Knowledge Regarding Higher Education}

\begin{tabular}{|c|c|c|c|}
\hline $\begin{array}{l}\text { S. } \\
\mathbf{N} \\
\mathbf{O}\end{array}$ & KNOWLEDGE & $\begin{array}{l}\text { YES } \\
\%\end{array}$ & $\begin{array}{l}\text { NO } \\
\%\end{array}$ \\
\hline 1 & $\begin{array}{l}\text { Are you aware of that there are quality } \\
\text { educational institutions in your reach? }\end{array}$ & 93 & 07 \\
\hline 2 & $\begin{array}{l}\text { Do you know that research has less } \\
\text { benefits as for higher education? }\end{array}$ & 49 & 51 \\
\hline 3 & $\begin{array}{l}\text { Do you know societal and industrial } \\
\text { demands leads to higher education? }\end{array}$ & 77 & 23 \\
\hline 4 & $\begin{array}{l}\text { Do you know current examination } \\
\text { system needs changes? }\end{array}$ & 64 & 36 \\
\hline 5 & $\begin{array}{l}\text { Do you know there } \\
\text { is no connection } \\
\text { between } \\
\text { professional respect } \\
\& \text { brain drain? }\end{array}$ & 27 & 73 \\
\hline 6 & $\begin{array}{l}\text { Do you know Technical study is } \\
\text { needed for higher education? }\end{array}$ & 91 & 09 \\
\hline 7 & $\begin{array}{l}\text { Do you know that equal } \\
\text { education is not } \\
\text { necessary for human } \\
\text { development? }\end{array}$ & 43 & 57 \\
\hline 8 & $\begin{array}{l}\text { Do you know the importance of quality } \\
\text { in higher education? }\end{array}$ & 92 & 08 \\
\hline 9 & $\begin{array}{l}\text { Do you know with passing time higher } \\
\text { education is getting more difficult. }\end{array}$ & 87 & 13 \\
\hline 10 & $\begin{array}{l}\text { Do you know there is no need of } \\
\text { improvements in higher education } \\
\text { system? }\end{array}$ & 38 & 62 \\
\hline
\end{tabular}

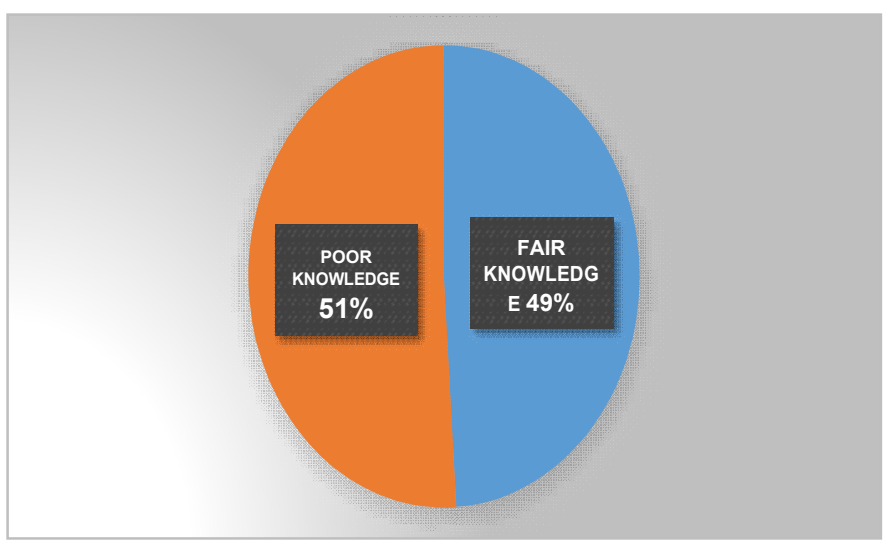

\section{Figure: 1- The Knowledge Level of the Students About Higher Education In India}

Regarding attitude the (Table 2) highlights that $27 \%$ of participants have fair attitude and $73 \%$ have poor attitude with mean 7.73 and SD $1.60 .96 \%$ of the students (Table. 4) wish to have development of quality educational institutions $94 \%$ of them accepts that higher education helps in meeting societal and industrial demands, but $50 \%$ said getting higher education is difficult nowadays which shows that the reality of getting education even for educated upper middle class family living in Urban. Then it becomes nightmare for the people from uneducated poor family in Rural area.

Among the participants only $27 \%$ of them are willing to respect the professionals highlights the missing of real respect to the educated leads to the major migration of well-educated intelligent professionals from India. 
TABLE- 4. Attitude Regarding Higher Education

\begin{tabular}{|c|c|c|c|}
\hline $\begin{array}{l}\text { S. } \\
\text { NO }\end{array}$ & $\begin{array}{l}\text { ATTI } \\
\text { TUDE }\end{array}$ & $\begin{array}{r}\text { AGREE } \\
\%\end{array}$ & $\begin{array}{l}\text { DISAGR } \\
\text { E } \%\end{array}$ \\
\hline 1. & $\begin{array}{l}\text { Developing quality educational } \\
\text { institutions are needed. }\end{array}$ & $96 \%$ & $04 \%$ \\
\hline 2. & $\begin{array}{l}\text { Conducting research is not useful in } \\
\text { higher education. }\end{array}$ & $37 \%$ & $63 \%$ \\
\hline 3. & $\begin{array}{l}\text { Higher education helps in meeting } \\
\text { societal \& industrial demands }\end{array}$ & $94 \%$ & $06 \%$ \\
\hline 4. & $\begin{array}{l}\text { Technical studies doesn't contributes in } \\
\text { higher education. }\end{array}$ & $35 \%$ & $65 \%$ \\
\hline 5. & $\begin{array}{l}\text { Due respect should be given for educated } \\
\text { and professional people. }\end{array}$ & $89 \%$ & $21 \%$ \\
\hline 6. & $\begin{array}{l}\text { Equality should be practiced in providing } \\
\text { higher education. }\end{array}$ & $83 \%$ & $27 \%$ \\
\hline 7. & $\begin{array}{l}\text { Getting higher education is easier } \\
\text { nowadays. }\end{array}$ & $50 \%$ & $50 \%$ \\
\hline 8. & $\begin{array}{l}\text { Higher education system needs some } \\
\text { positive changes. }\end{array}$ & $90 \%$ & $10 \%$ \\
\hline 9. & $\begin{array}{l}\text { Examination system is proper and not } \\
\text { required any change. }\end{array}$ & $45 \%$ & $55 \%$ \\
\hline 10. & $\begin{array}{l}\text { Should ensure quality education in higher } \\
\text { education. }\end{array}$ & $88 \%$ & $22 \%$ \\
\hline
\end{tabular}

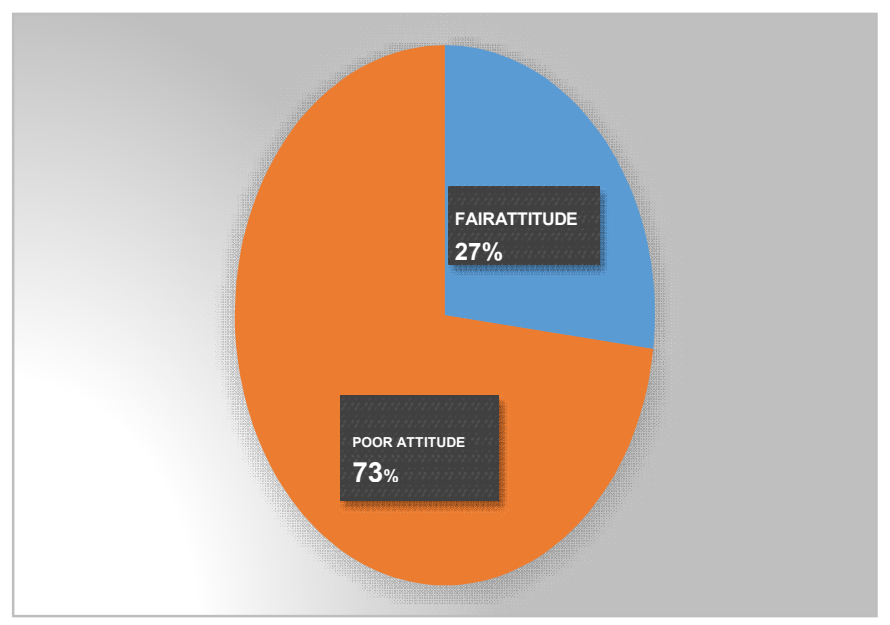

Figure: 2- The Attitude of Students about Higher Education In India
CONCLUSION: The study results highlights that there is a significant gap between knowledge and attitude of the students regarding higher education in India CONFLICT OF INTEREST

The authors declare no potential conflicts of interest with respect to the research, authorship, and/or publication of this article.

\section{Bibliography}

01. Indru Kumar B (2018)International Journal of Research and Innovation in Social Science (IJRISS) | Volume II, Issue VI, June 2018 | ISSN 2454-6186.

02. Rukmini S. (4 August 2015). "Only $8.15 \%$ of Indians are graduates, Census data show". The Hindu. Retrieved 1 April 2016.

03. Papola, TS ( 2014). An assessment of labour statistics system in India (PDF). Country office New Delhi: International Labor Organization, United Nations. Retrieved 9 November 2018.

04. Abhishek Shaw (2013). "Employment Trends in India: An Overview of NSSO's 68th Round". Economic and Political Weekly. 48 (42): 23-25. JSTOR 23528568

05. Mahesh Vyas, ( 2019); Business Standard for its methodology Unemployment, CMIE, Mumbai (2019) 06. Vyas, Mahesh (2018). "Using Fast Frequency Household Survey Data to 
Estimate the Impact of Demonetisation on Employment". Review of Market Integration. SAGE Publications. 10 (3): 159-183.

doi:10.1177/0974929218816586.

07. "Unemployment Statistics". www.labour.gov.in. Ministry of labour and employment. Retrieved 9 November 2018

08. Abhishek Shaw (19 October 2013). "Employment Trends in India: An Overview of NSSO's 68th Round". Economic and Political Weekly. 48 (42): 23-25. JSTOR 23528568
09. Indru Kumar B (2018)International Journal of Research and Innovation in Social Science (IJRISS) | Volume II, Issue VI, June 2018 | ISSN 2454-6186.

10. Surat,Present Scenario of Higher Education in India Dr.Kirti Matliwala Assistant Professor Department of Education VNSGU,

11. Younis Ahmad Sheikh,()Higher Education in India: Challenges and Opportunities .

12. Anuja Roy,Attitude of Public towards Higher Education:Conceptual Analysis, ChristUniversity,Bangalore,India.DOI:1 0.19085/journal.sijmas0212 